\title{
ODesenvolvimentismo no Brasil: o Debate Atual
}

\section{Developmentalism in Brazil: the Current Debate}

\author{
Mariana Finello* \\ Carmem Feijó**
}

Resumo: No debate atual sobre estratégias de crescimento de longo prazo, duas correntes principais se destacam dentro da ótica desenvolvimentista no Brasil: os novo-desenvolvimentistas e os social-desenvolvimentistas. Para ambas as estratégias, o investimento é a variável motriz do crescimento. Porém, a variável-chave para explicar o estímulo ao investimento é diferente para cada uma delas. Para a primeira corrente, a variável-chave deve ser a taxa de câmbio. Para a segunda, a variável-chave deve ser o consumo interno de bens de massa. A contribuição deste artigo é apresentar as duas agendas de política econômica, suas contribuições originais ao novo debate sobre desenvolvimentismo no Brasil e discutir como podem ser combinadas com objetivos de política econômica de curto prazo.

Palavras-chave: Desenvolvimentismo. Novo-desenvolvimentismo. Socialdesenvolvimentismo.

\begin{abstract}
The aim of this paper is to review the current debate in Brazil among the two main developmental group of authors named as the new developmentalists and the social developmentalists. For both groups, the investment is the main variable to explain growth. However, the key variable to push investment is different for either group. For the new developmentalists, the key variable is the exchange rate. For the second group, it is the domestic mass consumption. The contribution of this paper is to present both agendas of economic policy, their main contribution to the current debate on developmentalism in Brazil and discuss how they can be combine with the macroeconomic short-term economic policy.
\end{abstract}

Keywords: Developmentalism. New-developmentalism. Social-developmentalism.

JEL Classification: O11; O25; N66

* Mestranda em Economia pela Universidade Federal Fluminense (UFF). E-mail: finello.mari@ gmail.com

* $\quad$ Professora titular da Faculdade de Economia da Universidade Federal Fluminense (UFF). E-mail: cbfeijo@gmail.com 


\section{Introdução}

Entre a década de 1950 e o início da década de 1980, o desenvolvimentismo é considerado hegemônico ${ }^{1}$ dentro do pensamento econômico brasileiro. Entretanto, Bielschowsky e Mussi (2006) argumentam que a após esse período, durante a "era da instabilidade macroeconômica", a influência das ideias e das propostas de políticas desenvolvimentistas passou a ser descendente. $\mathrm{O}$ acirramento do processo inflacionário, encurtando o horizonte de tempo das decisões econômicas, restringiu o espaço para debates sobre os projetos de transformação de longo prazo, que foram substituídos por debates sobre políticas de estabilização econômica de curto prazo. Dito de outra forma, o combate à inflação persistente e alta, numa economia altamente indexada, dominou a agenda de política econômica até o sucesso do Plano Real, em 1994.

Com o aprofundamento da crise externa da década de 1980, formou-se um consenso, dentro e fora das correntes desenvolvimentistas, de que o projeto de desenvolvimento baseado no modelo de substituição de importações (MSI) havia se esgotado. Nesse mesmo período, com a retomada da hegemonia do pensamento neoliberal nas economias desenvolvidas, apoiado na revolução novo-clássica e novo-keynesiana no pensamento macroeconômico, os críticos do MSI internamente ganharam força. A grande questão que se colocava naquele momento era qual deveria ser o novo modelo para a retomada de crescimento da economia brasileira com o fim da inflação alta? Tanto a corrente neoliberal, quanto a desenvolvimentista apresentavam respostas distintas para essa indagação (FILGUEIRAS, 2006; BIELSCHOWSKY; MUSSI, 2006).

Para os neoliberais, o MSI não havia se esgotado, mas sim falhado. Dessa maneira, era necessário substituí-lo. Ao invés do protecionismo, a concorrência seria o novo dínamo do processo de crescimento econômico brasileiro. As propostas neoliberais eram pautadas em reformas que visavam o melhor funcionamento do mercado. Este proporcionaria a retomada do crescimento e a maior eficiência econômica. Essas reformas englobavam abertura comercial e financeira, ${ }^{2}$ além de um forte processo de desestatização da economia via privatizações (CARNEIRO, 2002; FILGUEIRAS, 2006).

Para os desenvolvimentistas, havia a necessidade de completar o processo de MSI, com a implantação no país dos setores intensivos em progresso técnico que compunham o novo paradigma tecnológico (biotecnologia, telecomunica-

1 A hegemonia do desenvolvimentismo não significa coesão. Existiam, nesse período, diferentes correntes desenvolvimentistas. Para saber mais, ver Bielschowsky (1988).

2 Carneiro (2002, p. 311) assinala que a abertura comercial seria uma estratégia de mão dupla: “[...] ao mesmo tempo em que levaria a uma maior concorrência nos mercados locais, também permitiria o acesso mais fácil aos mercados externos, isto é, o aumento de produtividade permitiria abrir novos mercados via aumento da competitividade". Ver também Barros e Goldstein (1997). 
ções, eletroeletrônica, entre outros). Através do processo de inovação ocorreria o aumento da produtividade e da competitividade da indústria nacional, que culminaria na retomada do desenvolvimento econômico. Em contraponto aos neoliberais, esse grupo é caracterizado pela crença na necessidade da atuação do Estado para a sustentação do crescimento e o aumento da eficiência econômica (BIELSCHOWSKY; MUSSI, 2006, p. 41-42).

Pode-se dizer que, por causa dessas tentativas, o Brasil foi o último país da América Latina a aderir ao projeto neoliberal. ${ }^{3}$ Essa adesão ocorreu de forma concreta com a eleição de Collor para presidente em 1990. Este aprofundou as medidas liberalizantes e as privatizações, que já estavam em curso desde o fim da década de 1980. Tais medidas são ainda mais potencializadas durante os governos de Fernando Henrique Cardoso, quando ocorreram as privatizações de gigantes, como a Vale do Rio Doce (1997) e a Telebras (1998), e com alterações institucionais importantes, como a flexibilização das contas CC $5^{4}$ (FILGUEIRAS, 2006; CARNEIRO, 2002).

Mesmo nesse cenário, segundo Bielschowsky (2014), não é possível considerar a corrente neoliberal hegemônica durante todo o período descrito. Para o autor, houve um rápido período de hegemonia devido aos efeitos do Plano Real a partir de 1995. Esse período foi abruptamente quebrado pelas crises dos Tigres Asiáticos e da Rússia em 1998, que evidenciaram a fragilidade macroeconômica da economia brasileira.

A primeira metade dos anos 2000 é marcada pelo boom das commodities. Assim, observou-se a retomada do crescimento com superávit nas transações correntes e a baixa inflação entre os anos de 2003 a 2007, o que, somado à rápida recuperação da crise em 2009, abriu espaço para que o debate sobre desenvolvimento fosse retomado com força extra. É possível afirmar que esse contexto propiciou uma superação parcial da "era da instabilidade", no qual foi possível avançar estratégias de desenvolvimento alternativas à neoliberal. Ou seja, retomaram-se os debates, tanto acadêmicos, quanto de prática política sobre políticas econômicas que visam o projeto de desenvolvimento de longo prazo (BIANCARELLI, 2012).

Nesse momento, trabalhos como o de Bresser-Pereira (2006) e de Sicsú, Paula e Michel (2005), que propõem estratégias de desenvolvimento alternativas à ne-

3 Filgueiras (2006, p. 179) chama a atenção para a diferença entre os termos "neoliberalismo" e "projeto neoliberal". O primeiro diz respeito à doutrina político-econômica, enquanto o segundo, à forma concreta pela qual o neoliberalismo se expressou num programa político-econômico no Brasil. Um marco na adesão ao projeto neoliberal pode ser visto também quando da inclusão do Brasil no Plano Brady para a renegociação da dívida externa, colocando ao término mais de uma década de difíceis negociações externas.

4 Carta Circular n ${ }^{\circ}$ 5, mais conhecida como "Contas CC5", foi estabelecida pelo Banco Central em 1969, para regulamentar as contas em moeda nacional mantidas no país, por residentes no exterior. Para maiores informações sobre a flexibilização das contas CC5, ver Carneiro (2002, p. 270-272). 
oliberal, ganharam destaque na discussão acadêmica heterodoxa. Mollo e Amado (2015) subdividem as correntes desenvolvimentistas da última década em três grupos: os novo-desenvolvimentistas, que se subdividem em novo-desenvolvimentistas precursores (BRESSER, 2006) e novo-desenvolvimentistas pós-keynesianos (SICSÚ; PAULA; MICHEL, 2005), e os social-desenvolvimentistas. ${ }^{5}$ Cada grupo possui uma variável-chave de destaque em sua retórica. Os novo-desenvolvimentistas precursores focam na taxa de câmbio competitiva para a indústria, enquanto a corrente novo-desenvolvimentista pós-keynesiana foca em taxa de juros mais baixas. Já para os social-desenvolvimentistas, o foco está na taxa de salário que deve viabilizar a sustentação do consumo de massas. Mesmo com essas diferenças, todas essas correntes perseguem um objetivo comum, "[...] um aumento de demanda que garanta impulso ao crescimento da economia, daí seu caráter heterodoxo [...]" (MOLLO; AMADO, 2015, p. 22).

O objetivo deste texto é apresentar as diferenças dentro da agenda desenvolvimentista, que visa traçar uma estratégia de política econômica que leve o país a um crescimento sustentável no contexto da liberalização econômica. Pretende-se contrapor as posições do novo-desenvolvimentismo precursor e do social-desenvolvimentismo, destacando-se as relações causais que dariam origem a trajetórias de crescimento com taxas mais elevadas e equilíbrio nos principais indicadores macroeconômicos. Como o debate entre as correntes desenvolvimentistas coloca novas alternativas de combinação de políticas macroeconômicas de curto prazo com vistas a criar espaço para a sustentação de um projeto de desenvolvimento econômico, este artigo busca também explorar essas possibilidades.

Além desta introdução, este artigo traça mais quatro seções: na segunda se analisa a conceituação do termo "desenvolvimentismo" feita por Fonseca (2014); na terceira se examina a estratégia novo-desenvolvimentista; na quarta se averigua a estratégia social-desenvolvimentista; e, por último, na quinta se delineiam as considerações finais sobre as duas propostas.

\section{Termo "Desenvolvimentismo"}

Dada a ampla utilização do termo desenvolvimentismo, torna-se necessário conceituá-lo. No entanto, como alerta Fonseca (2014), trata-se de uma tarefa árdua, já que esse termo tanto pode qualificar um fenômeno do mundo material, quanto um fenômeno do mundo do pensamento.

5 Para diferenciar essa corrente em relação ao desenvolvimentismo antigo, o termo proposto pelo próprio ministro Guido Mantega, em 2007, foi "social-desenvolvimentista”, logo “[...] é significativo que ele tenha sido proposto apenas em meados do segundo governo de Lula e pouco mais de dois anos depois da desaceleração de 2004-5, ainda que seus temas fossem apresentados no programa de governo de Lula na campanha presidencial de 2002." (BASTOS, 2012, p. 794). 
No primeiro caso, o termo é utilizado para caracterizar um conjunto de práticas de políticas econômicas, sendo executadas ou não. Essa conceituação geralmente aparece na literatura como Estado desenvolvimentista. Já no segundo caso, é utilizado para expor "[...] um conjunto de ideias que se propõe a expressar teorias, concepções ou visões de mundo." (FONSECA, 2014, p. 30). Esse conjunto pode se manifestar, tanto em forma de discurso político, quanto em forma de correntes de pensamento.

Em sua ampla pesquisa nas obras que utilizam o termo, Fonseca (2014) busca encontrar um núcleo comum de utilização para compará-lo com algumas experiências históricas latino-americanas. Segundo o autor, o núcleo duro desenvolvimentista seria composto por três aspectos: a) a existência de uma estratégia nacional intencionada que vise o desenvolvimento; b) a necessidade da intervenção estatal consciente para concretizá-la; e c) a industrialização como meio para o desenvolvimento. Dessa forma, o desenvolvimentismo é definido como:

[...] a política econômica formulada e/ou executada, de forma deliberada, por governos (nacionais ou subnacionais) para, através do crescimento da produção e da produtividade, sob a liderança do setor industrial, transformar a sociedade com vistas a alcançar fins desejáveis, destacadamente a superação de seus problemas econômicos e sociais, dentro dos marcos institucionais do sistema capitalista (FONSECA, 2014, p. 61).

O conceito construído pelo autor é maleável, no sentido de que consegue abranger as novas extensões do termo que surgiram no início dos anos 2000: o novo-desenvolvimentismo e o social-desenvolvimentismo. Ambas preservam o núcleo comum do conceito; apenas agregam a ele novas variáveis. No caso do novo-desenvolvimentismo, existe a preocupação com o equilíbrio fiscal e com a apreciação cambial real. Já no caso do social-desenvolvimentismo, existe a inclusão da redistribuição de renda como marca importante da estratégia de desenvolvimento.

\section{Novo-desenvolvimentismo ${ }^{6}$}

Os novo-desenvolvimentistas têm a taxa de câmbio competitiva para a indústria como o preço chave da economia. No processo de atualização das teses do "velho" desenvolvimentismo, os novo-desenvolvimentistas pressupõem não apenas a revisão das teses estruturalistas, ${ }^{7}$ mas também a inclusão de novos pressupostos. São incluídas cinco teses em relação ao antigo paradigma, dentre as

6 Por simplificação, a partir desse momento nos referimos ao novo-desenvolvimentismo precursor apenas como novo-desenvolvimentismo.

7 Para uma análise sobre a revisão feita pelos novo-desenvolvimentistas das teses estruturalistas, ver Bresser-Pereira e Gala (2012) e Bresser-Pereira (2012a). 
quais três estão relacionadas à taxa de câmbio. Essas novas teses são os pilares do novo-desenvolvimentismo e são apresentadas Quadro 1.

Quadro 1- As teses novo-desenvolvimentistas

\begin{tabular}{|l|}
\hline \multicolumn{1}{|c|}{ Teses novo-desenvolvimentistas } \\
\hline $\begin{array}{l}\text { A taxa de câmbio competitiva é essencial para o aumento da pou- } \\
\text { pança interna e do investimento. }\end{array}$ \\
\hline Tendência estrutural à sobrevalorização cíclica da taxa de câmbio. \\
\hline $\begin{array}{l}\text { Doença holandesa, que sobreaprecia permanentemente a taxa de } \\
\text { câmbio e impede ou dificulta a industrialização. }\end{array}$ \\
\hline $\begin{array}{l}\text { Crítica à política de déficit em conta corrente ou de crescimento } \\
\text { com poupança externa. }\end{array}$ \\
\hline Equilíbrio fiscal é essencial para o desenvolvimento. \\
\hline
\end{tabular}

Fonte: Adaptado de Bresser-Pereira e Gala (2012, p. 31).

O novo-desenvolvimentismo utiliza o mesmo método analítico da escola estruturalista. Bresser-Pereira e Gala (2012), Bresser-Pereira (2009) e Bresser-Pereira, Oreiro e Marconi (2015) o nomeiam como método histórico-dedutivo, ${ }^{8}$ caracterizado por partir da análise do fenômeno concreto para depois abstrair e modelar o objeto desejado. Dessa forma, seus modelos possuem um grau razoável de correspondência com a realidade. A dimensão histórica também faz parte dessa análise. O processo de desenvolvimento econômico é entendido como um fenômeno historicamente e institucionalmente determinado (BRESSER-PEREIRA, 2009; MOLLO; AMADO, 2015).

A influência da macroeconomia keynesiana está presente no protagonismo do papel da demanda na determinação do crescimento. Assim, no novo-desenvolvimentismo os entraves ao desenvolvimento estão concentrados, principalmente, no lado da demanda, e não no lado da oferta. Diferentemente da teoria neoclássica do crescimento, os problemas não são a disponibilidade dos fatores de produção - capital, trabalho e terra - e o progresso técnico (BRESSER-PEREIRA; OREIRO; MARCONI, 2015).

\subsection{A Estratégia de Crescimento Novo-Desenvolvimentista por meio de Exportações}

Os novo-desenvolvimentistas afirmam que um país que completou o seu processo de industrialização e alcançou um nível de renda média tem seu crescimento de longo prazo determinado pela expansão da demanda agregada. Para uma economia pequena, aberta e sem moeda conversível, o principal compo-

Mollo e Amado (2015) e Bielschowsky e Mussi (2006) utilizam o termo o "método históricoestrutural". 
nente autônomo são as exportações, cujo dinamismo é responsável por relaxar a restrição do balanço de pagamentos. Dessa forma, para a sustentação de uma taxa de crescimento de equilíbrio de longo prazo, as exportações devem crescer a uma taxa maior que as importações (BRESSER-PEREIRA; OREIRO; MARCONI, 2015).

Tendo identificado o mercado externo como o propulsor do crescimento a longo prazo, os novo-desenvolvimentistas identificam a taxa de investimento como a principal variável macroeconômica a explicar o crescimento do produto potencial. A taxa de investimento, por sua vez, dependeria das oportunidades de investimento voltadas para a exportação. A própria dinâmica do investimento faria com que a sua expansão simultaneamente aumentasse a capacidade produtiva e a disponibilidade de capital. Dessa forma, "[...] tanto o ritmo de crescimento da disponibilidade dos fatores de produção quanto o ritmo do progresso tecnológico são determinados, a longo prazo, pela taxa de expansão das exportações." (BRESSER-PEREIRA; OREIRO; MARCONI, 2015, p. 37).

Baseado em Kalecki (1983, p. 117), os novo-desenvolvimentistas assumem que o estoque de capital de uma economia é determinado pelas decisões passadas de investimento. Em nível da empresa, a decisão de investir depende principalmente de dois fatores: a percepção das oportunidades de lucros e o custo de oportunidade do capital. As oportunidades de lucro percebidas pelos empresários são resultado das expectativas da expansão da demanda por bens e serviços. Ou seja, a taxa de investimento se ajusta à expectativa de crescimento da demanda. Dessa forma, para que haja crescimento da taxa de investimento, a taxa de retorno do investimento dos empresários deve ser maior que o custo de oportunidade do capital. Como se verá, esse raciocínio está na base do argumento da importância da taxa de câmbio dentro da estratégia de desenvolvimento dos novo-desenvolvimentistas (BRESSER-PEREIRA; OREIRO; MARCONI, 2015).

Baseados nos escritos de Kaldor (1957), os novo-desenvolvimentistas assumem o progresso técnico como endógeno, ou seja, a introdução das inovações tecnológicas ao processo produtivo ocorre através do investimento em máquinas e equipamentos no "estado da arte" mundial.

Seguindo a tradição Keynes-Kalecki, a interconexão entre a taxa de investimento, a taxa de crescimento da economia e a taxa de lucro esperada mostra a impossibilidade de um crescimento sustentado de longo prazo ancorado no crescimento do mercado interno. Para um crescimento via mercado interno, os salários reais deveriam aumentar persistentemente, reduzindo a margem de lucro considerada satisfatória pelos empresários. Dessa maneira, a taxa de investimento se reduziria, acarretando uma atenuação da incorporação de progresso técnico, do crescimento da produtividade e da taxa de crescimento da economia. Se essa sequência ocorrer, a médio ou longo prazo, deve-se observar um crescimento dos salários maior que o crescimento da produtividade do trabalho, o que acarretaria 
uma aceleração do processo inflacionário. Utilizando os termos clássicos do artigo seminal de Bhaduri e Marglin (1990), os novo-desenvolvimentistas pressupõem que o investimento é mais sensível a mudanças na parcela dos lucros na renda que a mudanças no grau de capacidade utilizada. Ou seja, pressupõem que o regime de demanda seja profit-led e que não seja possível um crescimento sustentável em um regime wage-led (BRESSER-PEREIRA; OREIRO; MARCONI, 2015).

Destarte, distinguem-se dois tipos de investimento: o voltado para o mercado interno e o voltado para o mercado externo. Para o primeiro, a variável-chave é o consumo, que depende da taxa de crescimento da massa de salários. Para o segundo, as variáveis-chave são o crescimento da demanda mundial pelos bens exportados e a elasticidade-renda das exportações do país. Como já mencionado anteriormente, o foco dos novo-desenvolvimentistas são os gastos autônomos, dentre eles as exportações. Dessa forma, o potencial de crescimento de uma economia pequena, aberta e sem moeda conversível é determinado pela taxa de crescimento das exportações, expresso como:

$$
g=\varepsilon z(1.1)
$$

em que g é a taxa de crescimento do produto, $\varepsilon$ é a elasticidade-renda das exportações e $z$ é a taxa de crescimento da renda no resto do mundo (BRESSER-PEREIRA; OREIRO; MARCONI, 2015, p. 43).

A equação 1 sintetiza a relação estrutural entre o progresso técnico, o investimento e o crescimento econômico, e a sua interpretação dá sequência a um processo de causação circular cumulativa, a exemplo do modelo de Dixon e Thirwall (1975). O investimento reagiria à lucratividade esperada, que, por sua vez, dependeria da expectativa de crescimento da demanda e do custo de oportunidade do capital. O aumento do investimento estimularia a acumulação de capital por meio de introdução de máquinas e equipamentos, que incorporariam tecnologia de última geração à produção. Esse processo contribuiria para o aumento da produtividade agregada, propiciando um aumento da competitividade preço e não preço, ${ }^{9}$ ocasionando impacto positivo sobre as exportações, o que alteraria as expectativas sobre o crescimento da demanda do empresário, induzindo-o a um ajuste no seu investimento.

9 O termo "competitividade não preço" se refere à competitividade adquirida por meio do aumento da produtividade do trabalho. A taxa de lucro pode aumentar também por uma desvalorização cambial. Missio (2012, p. 98) salienta que nesse caso uma desvalorização cambial proporcionaria um aumento da taxa de lucro, que ocasionaria uma ampliação da capacidade de autofinanciamento das empresas. Essa ampliação facilitaria o acesso das empresas às novas tecnologias de produção disponíveis no mercado mundial. Dessa forma, nos países em desenvolvimento, uma parte do progresso tecnológico seria endógena ao nível da taxa real de câmbio. 
A contribuição dos novo-desenvolvimentistas ao descreverem o círculo virtuoso de crescimento traz para a discussão a necessidade de uma política cambial ativa, que garanta que a sequência descrita será observada.

\subsection{A Determinação da Taxa de Câmbio de Equilibrio e a sua Tendência à Apreciação Cíclica}

A taxa de câmbio é uma variável tão importante na argumentação dos novo-desenvolvimentistas que eles desenvolveram uma teoria própria para a sua determinação, baseados na teoria do valor dos economistas clássicos - Adam Smith e David Ricardo. Dessa forma, a taxa de câmbio possuiria um valor e um preço de mercado (BRESSER-PEREIRA; OREIRO; MARCONI, 2015).

O valor é definido traduzindo-se, para termos práticos, a ideia clássica de valor como trabalho socialmente necessário para a aquisição de bens e serviços em moeda estrangeira. Nesse sentido, o valor da taxa de câmbio seria dado como o custo de produção acrescido de uma taxa de lucro considerada razoável, que estimula as empresas que utilizam a tecnologia no "estado da arte mundial" a continuarem a produzir seus bens e serviços. Nas palavras dos autores, o valor da taxa de câmbio é definido como:

[...] o valor da moeda estrangeira expresso em termos de moeda nacional que permite às empresas representativas do país que participam do comércio exterior e garantem o equilíbrio de sua conta corrente obterem uma receita que cubra seus custos mais uma taxa de lucro razoável, assumida tarifa zero de importação. (BRESSER-PEREIRA; OREIRO; MARCONI, 2015, p. 58)

Organizando as empresas em ordem decrescente de competitividade, o valor da taxa de câmbio seria determinado pela última empresa que consegue participar do comércio internacional auferindo uma taxa de lucro considerada razoável pelos empresários. Mais especificamente, para determinar o valor da taxa de câmbio seria necessário analisar os custos de produção das empresas, os quais dependem da produtividade e dos salários. Quando os custos unitários do país subissem, o valor da moeda nacional cairia em decorrência da perda de competitividade econômica. Para que se mantivesse o equilíbrio no balanço de pagamentos, a taxa de câmbio deveria se depreciar. "Dessa forma, o país mantém competitivas suas empresas no plano monetário, embora esteja perdendo competitividade no plano econômico [...]" (BRESSER-PEREIRA; OREIRO; MARCONI, 2015, p. 58). Dada essa definição de valor para a taxa de câmbio, os autores estabelecem que a taxa de câmbio atingiria o equilíbrio quando o seu preço estivesse próximo do seu valor. 
O preço da taxa de câmbio seria determinado por dois fatores: pela oferta e demanda por moeda estrangeira e por um fator estrutural, a doença holandesa.

Bresser-Pereira $(2008,2012 b)$ considera a doença holandesa uma falha de mercado e uma desvantagem competitiva (BRESSER; OREIRO; MARCONI, 2015, p. 65) que atua na sobrevalorização da taxa de câmbio. Ou seja, distorce um preço macroeconômico básico da economia de maneira a afetar a competitividade de uma gama de empresas. A dinâmica de sobre apreciação está intimamente ligada às rendas ricardianas auferidas na exploração de recursos naturais abundantes. ${ }^{10}$ As rendas ricardianas entre países levam em conta o diferencial de produtividade de um país produtor em relação ao preço internacional da commodity. Ou seja, nos países onde os recursos naturais são abundantes e baratos, os custos de produção das commodities são menores em relação aos produtores marginais menos eficientes admitidos no mercado internacional e que estabelecem os parâmetros do preço internacional. Esse fato possibilita aos produtores mais eficientes auferirem lucros considerados extraordinários.

Dado esse panorama, a exportação de commodities é viável a uma taxa de câmbio que permite o equilíbrio da conta corrente determinado por essas mercadorias. Porém, essa taxa de câmbio será muito apreciada para tornar competitivas, em nível internacional, as empresas não produtoras de commodities que utilizam a tecnologia de fronteira. Dessa forma, essa taxa de câmbio se configura uma taxa de câmbio de equilíbrio "corrente", mas não uma taxa de taxa de câmbio de equilíbrio industrial. Ou seja, quando o país é sujeito à doença holandesa existiriam duas taxas de câmbio consideradas de equilíbrio de longo prazo - a corrente e a industrial. Por isso, a doença holandesa é considerada um fator estrutural que inibe a industrialização e a sofisticação produtiva (BRESSER-PEREIRA, 2006; BRESSER-PEREIRA; GALA, 2012; BRESSER-PEREIRA; OREIRO; MARCONI, 2015).

No caso específico do Brasil, Bresser-Pereira, Oreiro e Marconi (2015) argumentam que o país passa por um processo de desindustrialização por causa da doença holandesa. Para os autores, o país, com o MSI, neutralizou a doença holandesa através da implementação de taxas múltiplas de câmbio e altas alíquotas de importações. Porém, com a implementação de medidas de liberalização comercial e financeira, os instrumentos que antes neutralizavam a doença holandesa deixaram de ser implementados ou tiveram o seu papel reduzido.

Assim, os novo-desenvolvimentistas concluem que existe nos países em desenvolvimento uma "[...] tendência histórica à sobrevalorização cíclica e crônica [...]" da moeda nacional frente às moedas de referência (BRESSER-PEREIRA;

10 Segundo os novo-desenvolvimentistas, existiriam pelo menos duas outras fontes de doença holandesa, além da existência de recursos naturais abundantes e baratos: os grandes montantes de remessa de imigrantes e a existência de mão de obra barata associada à grande defasagem salarial. A primeira fonte seria a causa da doença holandesa no México e a segunda, nos países asiáticos (BRESSER-PEREIRA; OREIRO; MARCONI, 2015, p. 74-76). 
OREIRO; MARCONI, 2015, p.105). Essa tendência seria explicada tanto pela existência de um quadro de doença holandesa não neutralizada, quanto pela adoção de políticas econômicas que colaborariam para a sobrevalorização da taxa de câmbio. Assim, a tendência de sobrevalorização é considerada crônica por consequência do fator estrutural associado à doença holandesa e cíclica porque sua dinâmica respeita o ciclo de ocorrência das crises de balanço de pagamento (BRESSER-PEREIRA; OREIRO; MARCONI, 2015; BRESSER-PEREIRA, 2012b).

\subsection{Pollítica Macroeconômica e o Ciclo de Valorização do Câmbio}

Em um quadro de doença holandesa não neutralizada, a taxa de câmbio flutuaria em torno da taxa de equilíbrio "corrente". Porém, em virtude da implementação de políticas macroeconômicas específicas nos países em desenvolvimento, a taxa de câmbio se deslocaria para um patamar mais baixo que o do equilíbrio corrente. A principal política considerada equivocada pelos novo-desenvolvimentistas que contribui para essa tendência é a estratégia de crescimento via poupança externa. Além dessa, Bresser-Pereira, Oreiro e Marconi (2015) também destacam a utilização de duas outras políticas: a âncora cambial para conter a inflação e a prática de taxas de juros altas.

Quando a taxa de câmbio ultrapassa o nível do equilíbrio corrente, não seria mais possível garantir o equilíbrio intertemporal da conta corrente. O país passaria a gerar déficits que seriam cobertos por empréstimos internacionais e/ou pela entrada de capitais de curto prazo. No último caso, o elevado diferencial entre a taxa de juros doméstica e a internacional atuaria como um atrativo de fluxos de capitais que ocasionaria uma maior valorização da taxa de câmbio. Essa dinâmica é chamada na literatura como armadilha câmbio-juros (BRESSER-PEREIRA; GOMES, 2009; OREIRO, 2014). A reversão do ciclo de sobrevalorização do câmbio ocorreria de forma abrupta, resultado da percepção dos credores internacionais sobre a deterioração da situação da dívida externa do país. A reversão das expectativas sobre a capacidade de pagamento do país acarretaria uma crise de balanço de pagamentos, que, num primeiro momento, levaria a um overshooting cambial. Sem uma política cambial ativa, contudo, a taxa de câmbio voltaria a se valorizar e um novo ciclo de sobrevalorização se iniciaria.

Por hipótese, a taxa de crescimento da economia depende da taxa de investimento, que, por sua vez, está relacionada com a taxa de câmbio: os empresários calculariam a viabilidade dos seus investimentos tendo como base a taxa de câmbio de mercado. Como essa taxa não corresponde à taxa "correta", dada a tendência à sobrevalorização da taxa de câmbio em uma economia sujeita à doença holandesa e com políticas macroeconômicas que não a neutralizam, mesmo as empresas que utilizam a tecnologia de produção de fronteira considerariam seus 
investimentos economicamente inviáveis. Nesse cenário, os novo-desenvolvimentistas concluem que, para os países em desenvolvimento fazerem o catching-up, a tendência à sobrevalorização da taxa de câmbio deve ser neutralizada.

\subsection{Polliticas Cambiais Ativas}

A política cambial ativa possui duas frentes: a primeira está relacionada ao fator estrutural da doença holandesa; já a segunda, ${ }^{11}$ à oferta e à demanda de divisas internacionais, e depende, por um lado, de políticas convencionais - monetária e de compra de reservas - e, por outro lado, de políticas de controle de capital e de outras que evitem a sobrevalorização da taxa de câmbio.

A política cambial estrutural é aquela que tem como objetivo a neutralização da doença holandesa. Essa neutralização seria empreendida através de mecanismos que proporcionem a equalização das taxas de lucros dos setores exportadores de commodities e dos produtos industriais.

Alguns instrumentos de política econômica neutralizariam a doença holandesa. Um exemplo seria um sistema de taxas múltiplas de câmbio, altas alíquotas de importação e subsídios à exportação de bens industrializados. Porém, para os novo-desenvolvimentistas, existe um instrumento mais adequado para esse fim: a implementação de um imposto sobre a exportação da commodity, que proporciona rendas ricardianas aos seus produtores. Se um país possuir mais de uma commodity nessas condições, os impostos deveriam ser diferenciados, ou seja, específicos para cada uma delas (BRESSER-PEREIRA; OREIRO; MARCONI, 2015; BRESSER-PEREIRA, 2012b). Com a implementação do imposto sobre exportações, os custos de produção desses exportadores aumentariam em relação a outros países, o que aumentaria o valor da taxa de câmbio. Esse efeito acarretaria uma depreciação da taxa de câmbio para o nível equivalente ao equilíbrio industrial (BRESSER-PEREIRA; OREIRO; MARCONI, 2015, p. 160-161).

\subsection{Estratégias de Crescimento e Regimes de Demanda}

Por fim, para os novo-desenvolvimentistas, a análise do regime de demanda identifica três estratégias de crescimento: a domestic/wage-led, a export/profit$l e d^{12}$ e a equilibrada. Bresser-Pereira, Oreiro e Marconi (2015, p. 146) analisam a

11 "Na discussão da política cambial, partimos de duas hipóteses: a primeira, de que as exportações e importações são elásticas em relação à taxa de câmbio - isto é, a condição Marshall-Lerner está satisfeita - e a segunda, de que o regime cambial não é nem fixo nem totalmente flutuante, mas está sujeito a um regime administrado." (BRESSER-PEREIRA; OREIRO; MARCONI, 2015, p. 175)

12 Os termos wage-led e profit-led dizem respeito ao texto seminal de Bhaduri e Marglin (1990). Nesse artigo, se o investimento for mais sensível a mudanças no grau de capacidade utilizada, o regime é considerado wage-led. Porém, se o investimento for mais sensível a mudanças na parcela do lucro na renda, o regime seria profit-led. 
existência dessas estratégias através dos coeficientes de abertura e de exportação. Uma estratégia export-led seria caracterizada pelo crescimento do coeficiente de exportação e pela redução do coeficiente de abertura, enquanto a estratégia domestic-led seria caracterizada pela relação oposta. Já a estratégia equilibrada seria caracterizada pela estabilidade do crescimento de ambos os coeficientes.

A melhor estratégia de crescimento para um país de renda média seria a estratégia equilibrada, na qual tanto o mercado interno, quanto o externo são priorizados. Porém, quando um país apresenta taxas de crescimento econômico e de investimento abaixo do seu nível potencial, a estratégia export-led deveria ser utilizada no curto prazo para a reversão desse quadro e o alcance de um crescimento equilibrado. Ou seja, a estratégia export-led seria uma estratégia de transição para a estratégia de crescimento equilibrada. A estratégia domestic-led, por sua vez, não poderia se configurar como uma estratégia de transição, porque, para os autores, haveria limites para a expansão da participação dos salários na renda. ${ }^{13}$ Esses limites estariam dados pela expansão da capacidade produtiva, dado o baixo nível de investimento e pelo inevitável vazamento de renda, via importação de bens de consumo. Em suma, a estratégia domestic-led seria uma estratégia de curto prazo, da mesma forma que a estratégia export-led, porém que acarreta problemas de balanço de pagamentos e, portanto, não leva a um crescimento equilibrado no longo prazo como a estratégia export-led.

A estratégia export-led seria colocada em prática com uma desvalorização cambial "[...] realizada por uma série de intervenções, vamos imaginar, que a taxa de câmbio está no nível de equilíbrio industrial e que o governo é capaz de mantê-la nesse nível." (BRESSER-PEREIRA; OREIRO; MARCONI, 2015, p. 152). Como resultado dessa desvalorização, as oportunidades de investimento voltadas para o setor exportador iriam aumentar, pois as empresas que utilizam a tecnologia no estado da arte mundial não estariam mais em desvantagem por causa dos salários artificialmente altos em relação à produtividade do trabalho. A desvalorização cambial reduziria os salários reais e aumentaria a margem de lucro desses empresários e os estimularia a investir. O aumento da taxa de investimento proporcionaria um aumento similar na aquisição de máquinas e equipamentos modernos, que ocasionaria o aumento da produtividade do trabalho, que daria margem para o aumento salarial futuro. Esses efeitos contribuiriam para o ganho de competitividade não preço das exportações. $\mathrm{O}$ aumento das exportações iria puxar a produção voltada para o mercado interno e, dessa forma, contribuiria para uma maior dinamização tanto do mercado de trabalho, quanto do mercado interno de consumo. Logo, no longo prazo, o país atingiria um crescimento equilibrado.

13 “[...] no longo prazo não podemos pensar numa contínua redução da parcela dos lucros na renda nacional, uma vez que para manter a taxa de lucro constante, essa redução teria de ser compensada por um aumento contínuo do grau de utilização da capacidade, o que é impossível, pois seu limite é 1 (um)." (BRESSER-PEREIRA et al., 2015, p. 149). 
Os novo-desenvolvimentistas reconhecem que o ônus da desvalorização recairia sobre os trabalhadores, que veriam os seus salários reais diminuírem no curto prazo. Eles apenas seriam recompensados quando o círculo virtuoso se completasse, ou seja, quando a taxa de crescimento da economia e da demanda por mão de obra aumentassem. Nesse momento, os seus ganhos seriam superiores aos anteriores, pois os ganhos de produtividade seriam maiores que anteriormente. A existência do conflito distributivo não é negligenciada pelos novo-desenvolvimentistas (MISSIO, 2012, p. 100), e, portanto, admitem que seria necessária a construção de um pacto social, no qual os trabalhadores aceitassem uma redução dos seus salários reais no curto prazo em prol do crescimento acelerado e, consequentemente, maiores salários no longo prazo. Uma questão em aberto é como administrar o conflito distributivo no caso do círculo virtuoso não se comportar da maneira proposta.

\subsection{Análise Crítica da Sequência dos Argumentos Novo-Desenvolvimentistas}

Para o novo-desenvolvimentismo, a problemática do crescimento pode ser resumida como uma questão de ajuste de preços macroeconômicos, dos quais a taxa de câmbio é o preço mais importante na determinação da trajetória de crescimento de economias de renda média sujeitas à doença holandesa. Essa percepção assume que o estímulo ao setor industrial exportador seria capaz de dar o impulso para a superação dos problemas estruturais de baixa produtividade e baixa grau de desenvolvimento de progresso técnico, condições necessárias para o desenvolvimento das economias periféricas. Contudo, como alertam Mollo e Amado (2015), não há garantias de que os estímulos ao setor industrial exportador possam realinhar a estrutura do comércio exterior dos países periféricos de maneira a colocá-los em trajetória de catching up.

Carneiro (2012), por sua vez, assinala que a estratégia de incentivo ao setor exportador teve sucesso em países com mercado interno reduzido, como o caso dos países asiáticos na décadas de 1980 e 1990. Esses países conseguiram estabelecer a ponte entre crescimento das exportações de manufaturas via taxa de câmbio desvalorizada com a aquisição de progresso técnico e inovações produtivas. $\mathrm{O}$ Brasil possui uma estrutura diferenciada, na qual o mercado interno é relevante para indústria nacional de tal modo que é ele que dinamiza e produz alterações na estrutura produtiva. $\mathrm{O}$ autor também assinala que o debate sobre poupança externa no Brasil deve levar em consideração a conta financeira, fato pouco considerado no argumento novo-desenvolvimentista.

Por fim, os novo-desenvolvimentistas devem ter em mente que algumas das alterações ocorridas na configuração da estrutura produtiva nas duas últimas décadas não podem ser "concertadas" em âmbito nacional. Estão associadas tanto à 
mudança nas estratégias empresarias das firmas multinacionais em âmbito global, quanto a nova diretriz na ordem econômica mundial pró-liberalização. Ou seja, o "novo normal" seria caracterizado por coeficientes de abertura mais elevados.

\section{Social-Desenvolvimentismo}

A estratégia social-desenvolvimentista - também identificada como "modelo de desenvolvimento inclusivo", por Biancarelli et al. (2014, p. 16), e como "desenvolvimentismo distributivo orientado pelo Estado", por Bastos (2012, p. 793) - possui como eixo comum a ênfase em uma estratégia de desenvolvimento centrada na expansão do mercado interno, mais especificamente na expansão do mercado de consumo de massas (MOLLO; AMADO, 2015; BIELSCHOWSKY, 2014).

Segundo Biancarelli e Rossi (2013), o prefixo "social" assinala o papel de destaque que é atribuído à dimensão social dentro dessa estratégia e se justifica pela grande concentração de renda e de riqueza que o país apresenta, assim como os diferentes graus de desigualdade social e de oportunidades. As propostas teóricas que dão suporte às estratégias de política do social-desenvolvimentismo terão como referência maior a análise de Bielschowsky (2014). Nesses trabalhos, o autor apresenta as três principais fontes de expansão da economia brasileira e os seus dois mecanismos potencializadores, que podem guiar o país para um crescimento sustentável no longo prazo.

\subsection{A Estratégia de Crescimento Social-Desenvolvimentista via Consumo de Massas}

A primeira fonte de expansão da economia brasileira seria a expansão do mercado de consumo de massas, que ocorreria quando a renda per capita do país possibilitasse à população consumir acima das necessidades básicas. Medeiros (2015) demonstra que a evolução dos padrões de consumo ocorre através da incorporação de novos bens nas cestas de consumo devido à redução dos preços desses bens e dos bens-salário. A expansão dos bens duráveis na cesta de consumo depende de dois fatores adicionais: a estabilidade do emprego formal e a disponibilidade de crédito ao consumidor. "Nessa evolução, a mudança na estrutura relativa do consumo decorre da elevação da renda das famílias mais pobres e da adoção de novos hábitos de consumo - das famílias mais ricas." (MEDEIROS, 2015, p. 55). Ou seja, para que haja a estruturação e/ou a expansão do mercado de consumo de massas é necessário que o padrão, ou seja, a composição de consumo da sociedade evolua. 
A estrutura de distribuição de renda torna-se uma variável importante para determinar a evolução do padrão de consumo e, portanto, do crescimento econômico, como já apresentado por Furtado (1972). $\cdot{ }^{14} \mathrm{O}$ autor, analisando a década de 1960, afirma que a economia brasileira tendia a um processo de estagnação, fruto dos limites do modelo de acumulação excludente que vigorava na economia brasileira. A estagnação seria resultado da concentração da estrutura de demanda, que não possuía dinamismo suficiente para alterar a estrutura produtiva. A tese estagnacionista de Furtado (1972) foi refutada por Tavares e Serra (1983), ao analisarem o milagre econômico. Estes apontam que seria possível manter taxas altas de crescimento com uma estrutura de demanda concentrada, desde que os investimentos e as exportações tivessem papel de destaque na composição da demanda. ${ }^{15}$ Dessa forma, identificaram que o crescimento extraordinário do período foi perverso, pois não só gerou mais concentração de renda, como também foi induzido por esta.

Hoffmann e Duarte (1972) chegam à conclusão semelhante de que o crescimento do período foi reforçado pela concentração de renda. Trabalhos como o de Wells (1975) apresentam evidências de que a redistribuição de renda levaria a um aumento da demanda dos setores modernos mais que proporcionais aos ganhos de renda. Já o trabalho de Hoffman (1975) evidencia que mais da metade da população brasileira não teve efeitos monetários positivos com o crescimento econômico do milagre e que $30 \%$ tiveram apenas efeitos marginais. O autor elenca uma série de razões para esse resultado, como o crescimento dos salários menor que o crescimento da produtividade do trabalho, a adoção de tecnologias de produção intensivas em capital e a questão da concentração fundiária (BIELSCHOWSKY, 2014; BIELSCHOWSKY; MUSSI 2006; MALTA, 2010).

No início da década de 1990, Castro (2011b) argumenta que o mercado de consumo de massas estava estabelecido no Brasil. Esse processo teria ocorrido entre 1960 e 1988, quando o aumento do número de trabalhadores impactou no aumento da massa salarial, que, somado à disponibilidade de crédito ao consumidor, ocasionou o aumento do consumo de bens populares. Castro (2011a, p. 373-374) afirma que o aumento da massa salarial levaria a um aumento do investimento. Haveria uma intensa troca de estímulos entre os salários e o investimento, pois o aumento dos investimentos levaria à incorporação de novas técnicas de produção, aumentando a produtividade do trabalho e o espaço para os aumentos salariais. Castro chama a atenção para um fato: a revolução do consumo de massas não pressupõe que os salários cresçam mais rapidamente que a economia. Assim, afetaria a expansão da economia através do aumento da demanda e da produção

\footnotetext{
14 Antes da contribuição de Furtado, a interpretação dominante era da existência de uma economia dual, na qual coexistiam dois "Brasis", um moderno e outro atrasado (MALTA, 2010).

Vale observar que o próprio Furtado chegou a essa conclusão no livro Análise do modelo brasileiro, de 1972.
} 
de bens de consumo de massa e da ampliação da capacidade de produção desses bens. ${ }^{16}$

Bielschowsky (2014, p. 124), aprofundando a proposta de Castro, trabalha com a noção de um modelo de consumo e produção de massas. Ou seja, a expansão do mercado de consumo de massas deveria ser acompanhada de uma alteração na estrutura produtiva local para atender a essa demanda. Para o autor, apenas com a produção doméstica é possível que haja o aumento dos rendimentos de escala da produção e progresso técnico, seguindo o círculo virtuoso previsto por Castro (2011a). Por outro lado, o estancamento da demanda via aumento das importações pode comprometer o resultado do balanço de pagamentos no médio e longo prazo.

A análise feita por Castro (2011a) pressupõe uma abertura comercial racional: esperava-se que a retirada dos mecanismos de proteção ao mercado interno ocorresse de maneira paulatina, dando tempo para a indústria nacional se adaptar e ter capacidade de competir com os produtos importados. Porém, isso não ocorreu, pois a abertura comercial foi realizada rapidamente. Como resultado das reformas liberais, a estrutura de oferta nacional sofreu uma transformação ao longo da década de 1990, levando a uma especialização da estrutura produtiva. Para Carneiro (2002), esse processo é evidenciado na elevação do coeficiente de penetração da indústria, que passou de 5,7\%, em 1990, para 20,3\% em 1998 (CARNEIRO, 2002, p. 318). O processo de reestruturação produtiva teria sido intensificado pelo longo período de apreciação do real frente ao dólar, que barateou os produtos importados.

A análise da produção de massas no Brasil hoje possui outro problema: a produção da China. Esta possui custos menores e economia de escala na fabricação de muitos produtos industriais, e o próprio Castro (2008) reconhece que existem setores em que as empresas chinesas possuem um alto grau de competitividade, o que torna inviável a produção nacional, sem nenhuma forma de proteção ao mercado interno. ${ }^{17}$

16 Campolina e Silveira (2013) demonstram com dados da Pesquisa de Orçamento Familiar (POF), que desde 1988, a importância dos gastos com alimentação tem decaído, principalmente nos estratos mais pobres da população, ocasionando uma convergência lenta das cestas de consumo dos diferentes estratos de renda. Ou seja, a desigualdade de renda e a pobreza caíram, o que possibilitou que uma parcela importante da população acessasse o mercado de consumo de massas. Porém, esse acesso não teria significado ainda uma desconcentração nas despesas familiares, pois não teria havido ainda uma melhoria na distribuição do consumo. O consumo ainda é extremamente concentrado, principalmente o consumo de bens duráveis nas regiões metropolitanas.

17 Castro (2008, p. 4) afirma que "[...] os baixos salários chineses contribuíram para a redução inicial dos custos e preços - mas não explicam a drástica redução verificada nesta notável experiência." 


\subsection{Reindustrialização via Consumo de Massas, Incorporação Tecnológica na Exploração de Recursos Naturais e Investimento em Infraestrutura}

A proposta de um modelo de produção e consumo de massas (BIELSCHOWSKY, 2014, p. 124) é, na realidade, uma proposta de reindustrialização da economia brasileira. Contudo, como assinalado por Medeiros (2015), as mudanças ocorridas na distribuição de renda e nos padrões de consumo na última década não engendraram avanços na estrutura produtiva interna. A expansão do consumo de massas foi efeito a partir das inflexões da política econômica, conforme observadas por Biancarelli e Rossi (2013), acrescidas da estabilização dos preços dos produtos industriais, via valorização da taxa de câmbio e do aumento das importações chinesas.

Assim, Bielschowsky (2014) indica uma segunda fonte de expansão: a disponibilidade de diferentes tipos recursos naturais, que possuem tanto uma demanda nacional, quanto uma internacional. Castro (2008, p. 10) afirma que, no novo arranjo mundial, o Brasil seria "o grande provedor de alimentos" para um "[...] novo, diferente e rico mundo que teria a China por eixo industrial, em que a Índia seria a principal fonte fornecedora de serviços [...]". Para o autor, essa proposta não significa que o Brasil devesse assumir o papel de "fazenda do mundo", mas deveria ser entendida como um incentivo ao desenvolvimento de ramos industriais e de serviços de alta tecnologia que seriam demandados para aumentar a produção agrícola e a exploração de recursos naturais. Dessa forma, para que a expansão do setor exportador de commodities se traduzisse de fato em uma oportunidade para o desenvolvimento de longo prazo seria necessário agregar valor ao bem exportável e adensar a cadeia produtiva em território nacional. Para isso, os segmentos de beneficiamento de commodities e as indústrias produtoras de bens de capitais e intermediários utilizados em seus processos produtivos deveriam ser implementados e/ou expandidos ${ }^{18}$ (BIELSCHOWSKY, 2014).

A terceira fonte de expansão seria o investimento em infraestrutura econômica e social. Nesse caso, o setor público deveria desempenhar papel fundamental na dinamização do investimento, sendo o responsável pela elaboração direta de parte do investimento e também criando novas condições para induzir investimentos privados.

18 Deve-se observar que essa proposta tem uma clara influência da estratégia neoestruturalista, conforme apresentada no documento da Comisión Económica para América Latina y el Caribe (Cepal) de 1990, intitulado Transformación productiva con eqüidade. Essa estratégia se baseia na incorporação acelerada e contínua do progresso técnico, para que seja possível aumentar e sustentar a competitividade internacional, contribuindo para um forte crescimento das exportações. Dessa forma, a economia alteraria o seu padrão de inserção internacional. Por sua vez, essa alteração estaria relacionada com as transformações na estrutura produtiva setorial ou na articulação produtiva entre setores em escala mundial (RODRÍGUEZ, 2009, p. 544; BIELSHOWSKY, 2000). 
A percepção da importância do investimento em infraestrutura social como fonte de dinamização relevante se constitui em uma das propostas mais inovadoras dessa corrente de pensamento. A infraestrutura social (BIANCARELLI; ROSSI, 2013, p. 150), ou consumo público na concepção de Kerstenetzky (2016, p. 37), engloba os investimentos em educação, saúde, transporte coletivo, saneamento básico, entre outras atividades que impactam na condição de vida da população. ${ }^{19}$ Na visão dos autores, a expansão da infraestrutura social aumentaria não apenas o investimento agregado, mas, ao reduzir o déficit social do país, geraria impactos indiretos que alterariam positivamente a estrutura produtiva a longo prazo. Assim, os principais impactos indiretos são o aumento da produtividade do trabalho por meio da melhoria nas condições de vida dos trabalhadores, a partir do aumento da escolarização de qualidade e das condições de saúde, que, por sua vez, gerariam ganhos de competitividade não preço (BIANCARELLI; ROSSI, 2013; 150-151). Kerstenetzky $(2012,2016)$ ressalta que a expansão dos gastos com consumo público geraria impactos econômicos diretos através do aumento do emprego público nos segmentos de serviços sociais que impactaria diretamente sobre o consumo agregado e como mecanismo de suavização do consumo ao longo do ciclo econômico.

\subsection{Mecanismos Propagadores dos Estímulos à Reindustrialização}

Bielschowsky (2014, p. 129) argumenta que existem dois mecanismos que podem potencializar o dinamismo e os impactos das três fontes de expansão descritas na seção anterior: os encadeamentos produtivos e a geração de inovação.

A reconstituição e a criação de novos encadeamentos produtivos para frente e para trás permitem adensar a cadeia produtiva nacional dos setores considerados estratégicos para as três fontes expansão. Por outro lado, a geração de inovação na indústria nacional seria capaz de amplificar as três fontes de expansão, ampliando os seus efeitos multiplicadores sobre a renda e o emprego. Ela atuaria na transformação "[...] em núcleos estruturantes da economia nacional a várias atividades produtivas ainda inexistentes, ou em fase incipiente [...] e [permitiria] inaugurar ou reforçar a existência de encadeamentos produtivos com alta densidade tecnológica." (BIELSCHOWSKY, 2014, p. 116).

A combinação de ambos os potencializadores poderia promover uma mudança estrutural no parque produtivo nacional, garantindo a produção de bens

19 Kerstenetzky (2016, p. 37) define o consumo público como: “[...] as despesas do governo com a provisão de bens e serviços coletivos e individuais para as famílias e outros atores institucionais.". A autora salienta que o consumo público individual, como, por exemplo, saúde e educação, é um gasto genuinamente redistributivo e que afeta principalmente as famílias nos estratos de renda inferior. 
mais sofisticados tecnologicamente e agregando mais valor adicionado à produção nacional.

\subsection{A Política Macroeconômica Neoliberal e aEstratégia do Social-Desenvolvimentismo}

Rossi (2014) e Biancarelli e Rossi (2013), dentre outros, assim como os novo-desenvolvimentistas reconhecem que o regime macroeconômico adotado desde 1999 no Brasil é um fator complicador para a implementação da estratégia social-desenvolvimentista. Deve-se compreender o regime macroeconômico como um elemento estrutural da estratégia de desenvolvimento, como uma peça que pretende viabilizar, através do manejo das políticas macroeconômicas, a concretização dos objetivos dessa estratégia.

O Brasil, desde a crise cambial de 1999, adotou como regime macroeconômico o chamado "tripé macroeconômico", que se apoia em três pilares: regime de metas de inflação, taxas de câmbio flutuantes e metas de superávit primário.

Conforme aponta Fonseca (2014), a intencionalidade é uma palavra-chave para o desenvolvimentismo. Em termos de política econômica, pode-se traduzir intencionalidade como discricionariedade. Assim, podemos dizer que, na visão social-desenvolvimentista, o regime macroeconômico adotado no Brasil inibe a ação discricionária do setor público, através da adoção de metas rígidas que devem ser atingidas no curto prazo. Como visto, a estratégia social-desenvolvimentista pressupõe uma participação ativa do Estado, principalmente na condução da terceira fonte de expansão, o investimento em infraestrutura econômica e social. ${ }^{20}$ Ademais, a ênfase na estabilidade de preços com um regime de câmbio flutuante sem controle de capitais visa aumentar a potencialidade da política monetária, porém com consequências danosas ao câmbio, que tende a ser sobrevalorizado.

Porém, os críticos ao modelo do tripé macroeconômico dentro da corrente social-desenvolvimentista enfatizam que o modelo teórico do novo consenso macroeconômico admite certa flexibilidade na sua administração, desde que as autoridades econômicas desfrutem de credibilidade no mercado. Ou seja, para eles, seria possível implementar mudanças pontuais no regime macroeconômico para que este se adéque aos objetivos da estratégia social-desenvolvimentista. ${ }^{21} \mathrm{O}$

20 Biancarelli e Rossi (2013) apontam que o regime de metas de superávit fiscal praticado no Brasil não leva em consideração as fases do ciclo econômico e a relação endógena entre os gastos públicos e o crescimento econômico. Propõem o alongamento do cumprimento das metas fiscais e a implementação de mecanismos institucionais que permitam que as metas fiscais funcionem de maneira anticíclica.

21 Em relação ao regime de metas de inflação, os autores da corrente social-desenvolvimentista identificam, seguindo a escola estruturalista da inflação, a importância das pressões de custo e defendem um mix de políticas econômicas que perpassem as diferentes fontes da inflação (BIANCARELLI; ROSSI, 2013; SANTORO, 2015; BRAGA; BASTOS, 2010). 
Quadro 2 ilustra, por exemplo, situações em relação à política cambial que justificariam uma política cambial ativa (BIANCARELLI; ROSSI, 2013).

Quadro 2 - Motivos para uma política cambial ativa

\begin{tabular}{|l|l|l|}
\hline Tipos de política & Conta corrente & Conta financeira \\
\hline Administração da volatilidade & $\begin{array}{l}\text { Ciclo de preços } \\
\text { das commodities }\end{array}$ & $\begin{array}{l}\text { Excessos do merca- } \\
\text { do financeiro }\end{array}$ \\
\hline Administração do patamar & Doença holandesa & Carry trade \\
\hline
\end{tabular}

Fonte: Biancarelli e Rossi (2013, p. 155).

A primeira linha do quadro mostra como a conta-corrente e a conta financeira contribuem para a volatilidade no câmbio. A conta-corrente contribui para a volatilidade do câmbio pelo ciclo de preço das commodities, que tornam as receitas do setor exportador de commodities voláteis. À medida que as exportações de commodities ganham importância no total exportado, ${ }^{22}$ a oferta de divisas internacionais estará fortemente relacionada ao seu desempenho. A volatilidade de câmbio também pode ocorrer por movimento especulativo na conta financeira, que é potencializado pela manutenção de elevado nível da taxa de juros doméstica, principal instrumento de controle da inflação. A segunda linha do quadro mostra as forças que tendem a sobrevalorizar a taxa de câmbio. De um lado, há o efeito da doença holandesa, que é reconhecido pelos social-desenvolvimentistas, porém com menos ênfase que na corrente novo-desenvolvimentista (BIANCARELLI; ROSSI, 2013). De outro, há o impacto das operações de carry trade, que atuam como um importante mecanismo de transmissão do ciclo de liquidez internacional para a taxa de câmbio.

Exemplos de políticas cambiais específicas que poderiam ser adotas para atenuar os efeitos negativos sobre o câmbio seriam: a instituição de impostos sobre exportações de commodities ou a criação de fundos de estabilização para combater a doença holandesa contribuiriam para corrigir a tendência à apreciação do câmbio. Quanto à volatilidade, poderia ser controlada através de mecanismos de controle sobre os capitais de curto prazo $^{23}$ (BASTOS, 2012; ROSSI, 2012; BIANCARELLI; ROSSI, 2013).

Em relação à política fiscal, Biancarelli e Rossi (2013, p. 158-160) sugerem duas medidas com vistas a recuperar o seu caráter contracíclico: o alongamento

22 Segundo dados da Secretaria de Comércio Exterior (Secex), dentre os 15 produtos mais exportados no ano de 2014, 8 eram commodities: complexo da soja (14\%), minério de ferro $(12,6 \%)$, petróleo e combustíveis $(11,2 \%)$, carnes $(7,6 \%)$, açúcar e etanol $(4,6)$, papel e celulose $(3,2 \%)$, café $(2,9 \%)$ e, por fim, metais preciosos (1,3\%). Esses produtos representam $57,4 \%$ das exportações totais (BRASIL, 2015).

23 "Para esse propósito, é oportuno o uso de controles de capitais sobre os fluxos financeiros de curto prazo que são inerentemente voláteis e o uso de medidas regulatórias sobre o mercado de derivativos de câmbio." (BIANCARELLI; ROSSI, 2013, p. 156). 
do cumprimento das metas fiscais e a implementação de mecanismos institucionais que permitam o uso das metas fiscais de maneira anticíclica.

Em relação ao regime de metas de inflação, os autores ponderam que o processo de mudança estrutural que acompanha o processo de desenvolvimento acarreta pressões de custos. Dessa forma, o regime de metas inflacionárias sozinho não seria o mais adequado para combater de maneira eficaz à inflação, que deveria ser controlada por um mix de políticas econômicas que perpassem as suas diferentes fontes da inflação. ${ }^{24}$

\subsection{Análise Crítica do Círculo Virtuoso Social-Desenvolvimentista}

O círculo virtuoso de crescimento de longo prazo social-desenvolvimentista pressupõe que a expansão do mercado de consumo de massas irá estimular o investimento, que, por sua vez, afetará positivamente a produtividade e a competitividade que deverão impactar na geração de inovação e progresso técnico. A presença de economias de escala dinâmicas proporcionará a queda dos preços dos produtos industriais, que alimentará a expansão do consumo, reiniciando um novo ciclo de investimentos. Pelo lado da geração de renda, o aumento dos investimentos deverá aumentar a geração de empregos, expandindo a renda disponível, afetando positivamente o consumo dos trabalhadores. O aumento do consumo também afetará os rendimentos dos empresários, aumentando os seus lucros. Por fim, a arrecadação do governo também será afetada positivamente pelo aumento do emprego, da renda, do consumo e do lucro.

Um ponto crítico à estratégia social-desenvolvimentista é como dar sustentação a esse círculo virtuoso de crescimento em uma economia aberta e com elevada restrição externa. A variável-chave para a dinamização da economia através da produção e do consumo de massas é a garantia do poder de compra da classe trabalhadora. Porém, em uma economia aberta e integrada financeiramente, o poder de compra dos trabalhadores melhora à medida que o câmbio se aprecia. Por outro lado, uma taxa de câmbio apreciada se torna um poderoso instrumento para controle da inflação. Assim, a persistência de uma taxa de câmbio apreciada enfraquece o poder dinamizador do consumo de massas para alavancar o investimento privado. Por outro lado, a estratégia social-desenvolvimentista é fortemente amparada na intervenção de políticas públicas, e, portanto, o espaço para a atuação do Estado depende em grande parte do grau de autonomia da política econômica de curto prazo em relação ao setor externo. Até o presente, a combinação do tripé macroeconômico com as políticas de desenvolvimento com alcance de mais longo prazo tem sido limitada pelas condições externas enfrentadas pela economia brasileira. Isso pode ser inferido pelo fato de que as mudanças positivas ocorridas

$24 \quad$ Ver também Braga e Bastos (2010). 
na distribuição de renda nos anos 2000, bem como a expansão do consumo de massas não foram suficientes para promover uma mudança estrutural no sentido de relaxar a restrição externa de longo prazo.

\section{Considerações Finais}

Na longa apresentação dos principais pontos das novas teorias desenvolvimentistas que surgem na metade dos anos 2000 no Brasil - o novo-desenvolvimentismo e o social-desenvolvimentismo -, este texto objetivou mostrar como o debate sobre estratégias alternativas de desenvolvimento econômico ao modelo neoliberal se renovou no país. Partindo de um diagnóstico de que a experiência brasileira com o processo de crescimento baseado na industrialização via substituição de importações foi interrompido pela crise externa dos anos 1980 e pelo processo de alta inflação que dominou o país até meado dos anos 1990, a retomada do debate desenvolvimentista nos anos 2000 coloca em evidência a necessidade de se reindustrializar a economia brasileira.

A interpretação comum em ambas as correntes de pensamento é que a proposta de abertura econômica, como teria ocorrido a partir dos anos 1990, não colocou o país em trajetória de catching up com as economias mais avançadas. Ao contrário, o avanço da desindustrialização e a perda de competitividade da economia reduziram o seu potencial de crescimento de longo prazo. Em outras palavras, a abertura econômica e a estabilização de preços não recuperaram o vigor de crescimento como observado no pós-Guerra até os anos 1970 e não reduziram a dependência de poupança externa.

Dada essa perspectiva analítica, as duas correntes de pensamento desenvolvimentista abordadas neste texto apresentam argumentos distintos para a retomada do crescimento sustentável da economia brasileira, considerando o contexto de abertura econômica e de integração financeira. Em ambas encontram-se contribuições originais ao pensamento econômico brasileiro, o que reforça a importância da retomada do debate nos anos 2000. Porém, em ambas também pode-se apontar questões para reflexão sobre a transição para a implementação das estratégias de longo prazo. No que segue, tratar-se-á desses dois pontos.

\subsection{Destaques das Contribuições das Correntes Desenvolvimentistas no Debate Recente}

A corrente novo-desenvolvimentista desenvolveu uma original teoria de determinação da taxa de câmbio de equilíbrio industrial - ou seja, aquela taxa que permitiria à economia promover a mudança estrutural aprofundando o processo de industrialização com equilíbrio nas contas externas - para economias periféri- 
cas sujeitas à doença holandesa. Conforme mostrado pelos autores, economias com essas características apresentam uma tendência à apreciação cambial, o que inviabiliza a mudança estrutural na direção do relaxamento das restrições externas ao crescimento, caso a doença holandesa não seja neutralizada por medidas de política econômica. Por essa visão, uma vez que a política econômica produza os preços macroeconômicos "corretos", o processo de retomada do crescimento com mudança estrutural seria observado, tendo o mercado externo como o motor do crescimento a longo prazo.

A corrente social-desenvolvimentista, por sua vez, coloca a questão distributiva como central para a conquista de uma taxa de crescimento de longo prazo em patamar mais elevado para a economia brasileira. Isso porque é através de uma política de redistribuição de renda e riqueza que o mercado de consumo de massas se expandiria, o que permitiria sustentar o investimento produtivo e o crescimento do produto. Dada a dimensão continental da economia brasileira, o dinamismo do mercado interno é considerado o principal motor do crescimento e, dentre as forças de sustentação desse dinamismo, estaria o investimento em infraestrutura econômica e social. Baseado na experiência recente de políticas de redistribuição de renda no Brasil, os social-desenvolvimentistas, de forma pioneira, mostram que os impactos positivos dos investimentos em infraestrutura social se observam tanto no curto prazo, via expansão de renda e emprego, quanto no longo prazo pela melhoria na qualidade de vida da população com reflexo sobre a produtividade. Dessa forma, seria possível, do ponto de vista econômico e socialmente (mais) justo, sustentar políticas de transferência de renda e riqueza como estratégia de crescimento de longo prazo, viabilizando a mudança estrutural e recuperando a competitividade da economia brasileira.

\subsection{Questões na Transição para a Implementação das Estratégias Desenvolvimentistas}

No entanto, para a implementação das distintas estratégias, é necessário se discutir como implementá-las, dado o regime de política macroeconômico atual. Uma primeira consideração a ser feita é que as duas principais correntes desenvolvimentistas parecem tomar como um dado o arranjo de política macroeconômica em vigor, ou seja, o tripé macroeconômico, porém defendem alguma flexibilização no modelo macroeconômico de curto prazo. Assim, uma questão importante para reflexão é sinalizar qual parte do tripé é mais candidata a ser flexibilizada em uma ou outra corrente.

No caso do novo-desenvolvimentismo, claramente o maior problema na gestão da política econômica de curto prazo é a não neutralização da doença holandesa, com consequências danosas para a estrutura produtiva e para o crescimento a longo prazo. A ênfase na restrição externa ao crescimento leva os autores 
a proporem uma estratégia de crescimento na qual o setor externo deve liderar a expansão do PIB a longo prazo. Para tanto, a taxa de câmbio corrente deve ser mantida próxima daquela que permite a evolução da estrutura produtiva na direção de reduzir a restrição externa. Essa administração é complexa e depende de se formar um consenso sobre qual o nível da taxa de câmbio que atenderia à condição necessária para sustentar o crescimento dos investimentos produtivos. Nesse contexto, rejeitam políticas econômicas de curto prazo que valorizem o câmbio, como, por exemplo, a administração da taxa de juros básica no regime de metas de inflação atual, mantida sistematicamente em patamar elevado. Flexibilizar a meta de inflação implica, por outro lado, que a estabilidade de preços deve ser buscada com o equilíbrio do orçamento fiscal. Mesmo considerando que as metas fiscais devem observar as fases do ciclo econômico, os novo-desenvolvimentistas são mais favoráveis a programas de cortes de gasto público e menos favoráveis a desonerações fiscais como medida de ajuste. A questão distributiva seria melhorada como resposta ao aumento da produtividade e competitividade resultantes da mudança estrutural bem-sucedida, elevando a condição de vida da população ao longo do tempo.

No caso do social-desenvolvimentismo, o potencial do mercado doméstico é visto como o principal motor do crescimento. Assim, a política econômica de curto prazo deve manter e ampliar a renda dos trabalhadores, e, portanto, a melhora na distribuição de renda torna-se a prioridade da política econômica. A viabilidade de tal prioridade no curto prazo implica a defesa da flexibilização de metas fiscais - para garantir os gastos públicos com transferências e com investimento em infraestrutura - e das metas de inflação - que devem ser combinadas com outros instrumentos para controle de preços. Uma política cambial ativa deve ser implementada para controlar a volatilidade do câmbio e evitar a sua apreciação. A questão da desvalorização do câmbio é tratada com cautela, pois implica redução do poder de compra dos salários em moeda estrangeira ao mesmo tempo que alimenta a inflação. Nesse sentido, não é vista como prioridade de política econômica. Para essa corrente, a manutenção do dinamismo do mercado interno, através dos três motores dinamizadores do crescimento identificados, deve compensar os efeitos danosos da apreciação cambial sobre a estrutura produtiva a longo prazo. Essa é uma questão importante, pois pressupõe certa estabilidade do setor externo, condição que foge ao controle das autoridades econômicas do país. Assim, a corrente social-desenvolvimentista assume que o processo de retomada do crescimento em condições mais estáveis estaria assegurada através da melhoria na distribuição de renda com intervenção de políticas públicas, dado que o contexto internacional não provoque uma crise de balanço de pagamentos.

Uma segunda consideração é que as duas agendas de pesquisa reconhecem que a economia brasileira precisa avançar no processo de industrialização para 
alcançar uma taxa de crescimento sustentável mais elevada. Ou seja, a mudança estrutural é vista como fundamental para dar sustentação a um crescimento mais vigoroso. Para ambas as correntes, o investimento é a variável motriz do desenvolvimento, porém é trabalhado de uma forma diferente em cada uma delas. No caso dos novo-desenvolvimentistas, o investimento é considerado mais sensível a mudanças nas margens de lucro e na taxa de câmbio. Para os social-desenvolvimentistas, o investimento é considerado mais sensível a alterações nos investimentos públicos em infraestrutura econômica e social e à demanda por bens de consumo de massa.

O Quadro 3 sintetiza os aspectos principais das estratégias desenvolvimentistas, conforme discutido nas seções 3 e 4 deste artigo. A principal diferença entre as correntes desenvolvimentistas encontra-se no foco indutor do crescimento a longo prazo: mercado externo para os novo-desenvolvimentistas e mercado interno para os social-desenvolvimentistas. Ambas as correntes concordam que o investimento deve ser o principal componente da demanda agregada a puxar o crescimento, sendo, no entanto, que a variável indutora, no caso dos novo-desenvolvimentistas, deve ser a taxa de lucro e, para os social-desenvolvimentistas, o comportamento da demanda agregada, expresso na variável grau de capacidade utilizada.

Quadro 3 - Comparação entre as estratégias desenvolvimentistas

\begin{tabular}{|l|l|l|}
\hline \multicolumn{1}{|c|}{ Característica } & \multicolumn{1}{|c|}{$\begin{array}{c}\text { Novo-desenvolvi- } \\
\text { mentismo }\end{array}$} & \multicolumn{1}{|c|}{$\begin{array}{c}\text { Social-desenvolvi- } \\
\text { mentismo }\end{array}$} \\
\hline $\begin{array}{l}\text { Principal indutor do cres- } \\
\text { cimento }\end{array}$ & Mercado externo & Mercado interno \\
\hline $\begin{array}{l}\text { Principal componente da } \\
\text { demanda agregada }\end{array}$ & Investimento & Investimento \\
\hline $\begin{array}{l}\text { Maior sensibilidade do } \\
\text { investimento }\end{array}$ & Taxa de lucro & $\begin{array}{l}\text { Grau de capacidade } \\
\text { utilizada }\end{array}$ \\
\hline $\begin{array}{l}\text { Variável-chave de políti- } \\
\text { ca macroeconômica }\end{array}$ & Taxa de câmbio & Taxa de salário \\
\hline
\end{tabular}

Fonte: Elaboração própria.

Por fim, a variável-chave para a administração da política macroeconômica distancia as duas estratégias. Para os novo-desenvolvimentistas, a partir do diagnóstico da presença da doença holandesa, a atenção com a taxa de câmbio deve ser o alvo principal da política econômica de curto prazo. Para os social-desenvolvimentistas, a questão distributiva deve orientar as decisões de política econômica, e, portanto, a preservação do poder de compra dos salários deve ser observada.

Assim, pode-se ver que o debate desenvolvimentista atual se desdobra em como, dentro do regime macroeconômico vigente no país, a economia brasileira pode retomar uma trajetória virtuosa de crescimento. Partindo de uma base co- 
mum de rejeição ao modelo neoliberal de desenvolvimento, ambas as correntes, em grau diferenciado, veem a necessidade de uma mudança estrutural, ou seja, um processo de reindustrialização, com melhora na distribuição de renda. Talvez uma síntese do debate possa ser colocada da seguinte forma: o que privilegiar no curto prazo? A melhoria da competitividade industrial, o que implica em patamar mais elevado para a taxa de câmbio, ou avançar na política de distribuição funcional de renda como força motriz para a retomada do crescimento? Como ponto de divergência entre as duas correntes está o embate de ideias sobre qual combinação de política de curto prazo será mais eficaz para se alcançar a meta de mais crescimento com maior equidade social.

\section{Referências}

BARROS, J. R; GOLDENSTEIN, L. Avaliação do processo de reestruturação industrial Brasileiro. Revista de Economia Política, v. 17, n. 2 (66), p. 11-31, abr.jun. 1997.

BASTOS, P. P. Z. A economia política do novo-desenvolvimentismos e do social desenvolvimentismo. Economia e Sociedade, v. 21, n. especial, p. 779-810, dez. 2012. Disponível em: <http://www.scielo.br/pdf/ecos/v21nspe/v21nspea04> . Acesso em: 15 mar. 2015.

BHADURI, A.; MARGLIN, S. Unemployment and the real wage: the economic basis for contesting political ideologies. Cambridge Journal of Economics, v. 14, n. 4, p. 375-393, 1990.

BIANCARELLI, A. M. et al. Introdução. In: CALIXTRE, A. B.; BIANCARELLI, A. M.; CINTRA, M. A. C. (Org.). Presente e futuro do desenvolvimento Brasileiro. Brasília, DF: Ipea, 2014.

BIANCARELLI, A. M.; ROSSI, P. L. A política macroeconômica em uma estratégia social desenvolvimentista. In: FONSECA, A.; FAGNANI, E. (Org.). Políticas sociais, desenvolvimento e cidadania: economia, distribuição da renda e mercado de trabalho. São Paulo: Fundação Perseu Abramo, 2013. Disponível em: <http://novo.fpabramo.org.br/sites/default/files/fpacomunica-ppb-07.pdf>. Acesso em: 09 maio 2015.

BIELSCHOWSKY, R. Pensamento econômico brasileiro: o ciclo ideológico do desenvolvimentismo. Rio de Janeiro: Ipea; Inpes, 1988.

BIELSCHOWSKY, R. Cinquenta anos de pensamento na Cepal: uma resenha. In: BIELSCHOWSKY, R. (Org.). Cinquenta anos de pensamento na CEPAL. Rio de Janeiro: Record, 2000.

BIELSCHOWSKY, R. Estratégia de desenvolvimento e as três frentes de expansão no Brasil: um desenho conceitual. In: CALIXTRE, A. B.; BIANCARELLI, A. M.; CINTRA, M. A. C. (Org.). Presente e futuro do desenvolvimento brasileiro. Brasília, DF: Ipea, 2014.

BIELSCHOWSKY, R.; MUSSI, C. El pensamiento desarrollista en Brasil: 1930-1964 y anotaciones sobre 1964-2005. In: CAVE, R. Brasil y Chile: una mirada hacia América Latina. Santiago del Chile: RIL Editores, 2006. 
BRAGA, J.; BASTOS, C. P. M. Conflito distributivo e inflação no Brasil: uma aplicação ao período recente. In: VIANNA, S. T. W.; BRUNO, M. A. P.; MODENESI, A. M. (Org.). Macroeconomia para o desenvolvimento: crescimento, estabilidade e emprego. Perspectivas do desenvolvimento Brasileiro. Brasília, DF: Ipea, 2010. Livro 4.

BRESSER-PEREIRA, L. C. O novo desenvolvimentismo e a ortodoxia convencional. São Paulo em Perspectiva, São Paulo, v. 20, n. 3, p. 5-24, 2006.

BRESSER-PEREIRA, L. C. The Dutch disease and its neutralization: a Ricardian approach. Revista de Economia Política, v. 1, n. 28, p.47-71, jan. 2008.

BRESSER-PEREIRA, L. C. Os dois métodos e o núcleo duro da teoria econômica. Revista de Economia Política, v. 29, n. 2 (114), p. 163-190, abr.jun. 2009.

BRESSER-PEREIRA, L. C. Do antigo ao novo desenvolvimentismo na América Latina. In: DELORME PRADO, L. C. (Org.). Desenvolvimento econômico e crise. Rio de Janeiro: Contraponto Editora, 2012a.

BRESSER-PEREIRA, L. C. A taxa de câmbio no centro da teoria do desenvolvimento. Estudos Avançados, São Paulo, v. 26, n. 75, p. 7-28, maio/ago. 2012b. Disponível em: < http://www. bresserpereira.org.br/view.asp?cod=4532>. Acesso em: 09 maio 2015.

BRESSER-PEREIRA, L. C.; GALA, F. O novo desenvolvimentismo e apontamentos para uma macroeconomia estruturalista do desenvolvimento. In: OREIRO. J. L. et al. Macroeconomia do desenvolvimento. Recife: Editora Universitária UFPE, 2012.

BRESSER-PEREIRA, L. C.; GOMES, C. O regime de metas de inflação no Brasil e a armadilha da taxa de juros/taxa de câmbio. In: OREIRO, J. L.; PAULA, L. F.; SOBREIRA, R. (Org.). Política monetária, bancos centrais e metas de inflação: teoria e experiência brasileira. Rio de Janeiro: Editora FGV, 2009. v. I. p. 21-51. Disponível em: < http://www.bresserpereira.org. br/papers/2007/07.04.metas_inflacao-cleomar-livro.mar.22.pdf>. Acesso em: 09 maio 2015.

BRESSER-PEREIRA, L. C.; OREIRO, J. L.; MARCONI, N. Macroeconomia estruturalista do desenvolvimento: teoria e política econômica do novo desenvolvimentismo. São Paulo: Elsevier, 2015.

CAMPOLINA, B.; SILVEIRA, F. G. A heterogeneidade estrutural e o consumo de massa no Brasil. In: CASTRO, I. S. B. (Org.). Novas interpretações desenvolvimentistas. Rio de Janeiro: E-Papers, 2013. v. 4. p. 249-28.

CARNEIRO, R. Desenvolvimento em crise: a economia brasileira no último quarto do século XX. São Paulo: Editora UNESP, 2002.

CARNEIRO, R. Velhos e novos desenvolvimentismos. Economia e Sociedade, v. 21, n. especial, p. 749-778, dez. 2012.

CASTRO, A. B. O Brasil a caminho do mercado de massas. In: VELLOSO, J. P. R. O desenvolvimento brasileiro da era Geisel ao nosso tempo. Rio de Janeiro: INAE, $2011 \mathrm{a}$, p. 365-372., 
CASTRO, A. B. Consumo de massa e retomada de crescimento. In: VELLOSO, J. P. R. O desenvolvimento brasileiro da era Geisel ao nosso tempo. Rio de Janeiro: INAE, $2011 \mathrm{~b}, \mathrm{p}$. 373-385.

CASTRO, A. B. No espelho da China. Unicamp, p. 1-13, 2008. Disponível em: < http://www. gr.unicamp.br/ceav/content/pdf/pdf_textobrasilnoespelhodachina.pdf $>$. Acesso em: 09 maio 2015.

COMISIÓN ECONÓMICA PARA AMÉRICA LATINA Y EL CARIBE. Transformación productiva con equidad. Santiago del Chile: Publicação das Nações Unidas, mar. 1990. (Série Libros de la Cepal, n. 25).

DIXON, R. J.; THIRLWALL, A. P. A model of regional growth-rate differences on Kaldorian lines. Oxford Economic Papers, v. 27, p. 201-214, 1975.

FILGUEIRAS, L. O neoliberalismo no Brasil: estrutura, dinâmica e ajuste do modelo econômico. In: BASUALDO, E. M.; ARCEO, E. Neoliberalismo y sectores dominantes: tendencias globales y experiencias nacionales. Buenos Aires: Consejo Latinoamericano de Ciencias Sociales, ago. 2006.

FONSECA, P. C. D. Desenvolvimentismo: a construção do conceito. In: CALIXTRE, A. B.; BIANCARELLI, A. M.; CINTRA, M. A. C. (Org.). Presente e futuro do desenvolvimento Brasileiro. Brasília, DF: Ipea, 2014.

FURTADO, C. Análise do modelo brasileiro. Rio de Janeiro: Civilização Brasileira, 1972.

HOFFMANN, R; DUARTE, J. C. A distribuição de renda no Brasil. Revista de Administração de Empresas, São Paulo, v. 12, n. 2, p. 46-66, 1972.

HOFFMAN, $R$ Tendências da distribuição da renda no Brasil e suas relações com o desenvolvimento econômico. In: TOLIPAN, R.; TINELLI, A. C. A. Controvérsia da distribuição de renda no Brasil. Rio de Janeiro: Zahar Editores, 1975.

KALDOR, N. A model of economic growth. The Economic Journal, v. 67, n. 268, p. 591-624, Dec. 1957.

KALECKI, M. Teoria da dinâmica econômica: ensaio sobre as mudanças cíclicas e a longo prazo da economia capitalista. São Paulo: Abril Cultural, 1983.

KERSTENETZKY, C. L. O estado do bem-estar social na idade da razão. Rio de Janeiro: Campus/Elsevier, 2012.

KERSTENETZKY, C. L. Consumo e crescimento redistributivo: notas para se pensar um modelo de crescimento para o Brasil. Revista de Economia Política, v. 36, n. 1 (142), p. 29-45, jan./mar. 2016.

MALTA, M. M. A controvérsia da distribuição de renda no pensamento econômico Brasileiro: a ampliação do debate teórico sob a conjuntura política dos anos 1970. In: ENCONTRO DA ANPEC, 38., 2010, Salvador. Anais... Salvador: ANPEC, 2010. v. 1. p. 1-20.

MEDEIROS, C. A. Inserção externa, crescimento e padrões de consumo na economia Brasileira. Brasília, DF: Ipea, 2015. 174 p. 
MISSIO, F. Câmbio e crescimento na abordagem Keynesiana-estruturalista. 2012. 276 f. Tese (Doutorado em Economia) - Faculdade de Ciências Econômicas, Universidade Federal de Minas Gerais, Minas Gerais, 2012. Disponível em: < http://www.bibliotecadigital.ufmg.br/ dspace/handle/1843/AMSA-954M4M > . Acesso em: 09 abr. 2015.

MOLLO, M. L. R.; AMADO, A. M. O debate desenvolvimentista no Brasil: tomando partido. Economia \& Sociedade, v. 24, p. 1-28, 2015.

OREIRO, J. L. A armadilha juros-câmbio: a continuidade do desequilíbrio macroeconômico Brasileiro. Revista de Conjuntura, Brasília, DF, n. 52, p. 34-42, abr. 2014. Disponível em: <http://joseluisoreiro.com.br/site/link/4f6b8ff288a9e7e5ed0538539b4c593e962ad30d.pdf>. Acesso em: 20 abr. 2015.

RODRÍGUEZ, O. O estruturalismo latino-americano. Rio de Janeiro: Civilização Brasileira, 2009.

ROSSI, P. L. Taxa de câmbio no Brasil: dinâmica da especulação e da arbitragem. 2012. 189 f. Tese (Doutorado em Ciências Econômicas) - Instituto de Economia, Universidade Estadual de Campinas, Campinas, 2012.

ROSSI, P. L. Regime macroeconômico e o projeto social-desenvolvimentista. In: CALIXTRE, A.; BIANCARELLI, A.; CINTRA, M.A. (Org.). Presente e futuro do desenvolvimento brasileiro. Brasília, DF: Ipea, 2014.

BRASIL. Ministério do Desenvolvimento, Indústria e Comércio Exterior. Secretaria de Comércio Exterior. Disponível em: <http://www.desenvolvimento.gov.br//arquivos/ dwnl_1423144482.pdf>. Acesso em: 03 jul. 2015.

SICSÚ, J.; PAULA, L. F.; MICHEL, R. Por que novo-desenvolvimentismo? In: SICSÚ, J. PAULA, L. F.; MICHEL, R. (Org.). Novo-desenvolvimentismo: um projeto nacional de crescimento com equidade social. São Paulo: Manole, 2005.

TAVARES, M. C.; SERRA, J. Além da estagnação. In: TAVARES, M. C. Da substituição de importações ao capitalismo financeiro. 11. ed. Rio de Janeiro: Zahar Editores, 1983. p. 153-172.

WELLS, J. Distribuição de rendimento, crescimento e estrutura de demanda no Brasil na década de 60. In: TOLIPAN, R.; TINELLI, A. C. (Org.). A controvérsia da distribuição de renda no Brasil. Rio de Janeiro: Zahar Editores, 1975.

WILLIAMSON, J. G. Strategic wage goods, prices, and inequality. American Economic Review, v. 67, n. 2, p. 29-41, Mar. 1977.

Recebido em: 15/09/2015. Aceito em: 06/06/2016. 